Research Article

\title{
Molecular Interaction Analysis of COX-2 Against Aryl Amino Alcohol Derivatives from Isoeugenol as Anti Breast Cancer using Molecular Docking
}

\author{
Zulfa Zuhrufa ${ }^{1}$, Tatang Shabur Julianto2,* \\ ${ }^{1}$ Master Program of Chemistry, Department of Chemistry, Universitas Islam Indonesia, \\ Jl. Kaliurang Km 14, Sleman, Yogyakarta, 55584, Indonesia. \\ ${ }^{2}$ Department of Chemistry, Universitas Islam Indonesia, Jl. Kaliurang Km 14, Sleman, Yogyakarta, \\ 55584, Indonesia.
}

Received: $8^{\text {th }}$ February 2021; Revised: 1st June 2021; Accepted: $2^{\text {nd }}$ June 2021

Available online: 3rd June 2021; Published regularly: September 2021

\section{Abstract}

Breast cancer occurs due to uncontrolled cells proliferation. The Proliferation causes severe inflammatory which can be the initial stages of cancer symptoms. Aryl amino alcohol compounds from isoeugenol derivatives are proposed for the potential drugs of breast cancer. This study was conducted on iso-eugenol derivatives by adding carbonyl groups, hydroxyl groups, halide compounds and amines to determine the effect on anticancer activity through molecular docking studies. The molecular docking approach is carried out to see the interaction of ligands with protein compounds by using the minimized ligand energy bind with protein active site using protein data bank ID 5GMN. The docking result show that IE-Benzanilide-Cl (11) and IE-Benzanilide-OH (10) have the lowest binding energy $(-8.3 \mathrm{kcal} / \mathrm{mol}$ and $-8.6 \mathrm{kcal} / \mathrm{mol})$ compare to another compounds. AdmetSAR computer simulations show that all compounds have very few toxic effects. The use of aryl amino alcohol derivatives (10 and 11) may be suggested as anti-breast cancer drugs.

Copyright (C) 2021 by Authors, Published by BCREC Group. This is an open access article under the CC BY-SA License (https://creativecommons.org/licenses/by-sa/4.0).

Keywords: Breast Cancer; Molecular Docking; Aryl Amino Alcohol; Iso-Eugenol; Proliferation

How to Cite: Z. Zuhrufa, T.S. Julianto (2021). Molecular Interaction Analysis of COX-2 Against Aryl Amino Alcohol Derivatives from Isoeugenol as Anti Breast Cancer using Molecular Docking. Bulletin of Chemical Reaction Engineering \& Catalysis, 16(3), 581-587 (doi:10.9767/bcrec.16.3.10324.581-587)

Permalink/DOI: https://doi.org/10.9767/bcrec.16.3.10324.581-587

\section{Introduction}

Cancer is a global health problem and a leading cause of death after cardiovascular disease [1]. The first type of cancer that affects women is breast cancer [2]. According to the Registration of Pathology in Indonesia, breast cancer was the first rank with a relative frequency of $18.6 \%$. The report during 2018 has been found 16,956 cases of breast tumors and 2,253 sus-

\section{* Corresponding Author}

Email: 19923014@students.uii.ac.id (Z. Zuhrufa); tatang.shabur@uii.ac.id (T.S. Julianto) pected breast cancer in Indonesia. Over $80 \%$ of breast cancer cases are found at more difficult stages of treatment [3].

A few researchers found that the breast cancer is closely linked to the inflammatory effect [4-7]. The enzyme cyclooxygenase 2 (COX-2) is controlled the inflammation. This enzyme is responsible for regulating the response to pain. With regard to this correlation, compounds that can inhibit the cyclooxygenase 2 enzyme can be turned into drugs against breast cancer. The commercial medicine for anti-inflammatory drug which use in the treatment of cancer is 
Polmacoxib. However, the consumption of this drug has adverse health effects, including an increase of $37 \%$ cardiovascular disease [8].

The mechanism of interaction between iso eugenol and the cyclooxygenase 2 (COX-2) enzyme can be determined by molecular docking methods. This in silico method is a combination of structural molecules and computer medicine. The purpose of this method is to use the free energy of interaction $(\Delta \mathrm{G})$ to obtain information about the three-dimensional interaction of protein and ligand (suggested compounds). The information of bonding type and interaction ability provide data capable of inhibiting active compound on specific receptor which plays a role in the development of disease [9]. Previous studies have reported that the molecular docking of the amino alcohol derivatives of eugenol can inhibit the growth of human colon cancer. Derivatives with a hydroxyl functional groups in the aromatic ring can improve the hydrophilic properties and interaction at the active site of protein [10].

Other research focused on eugenol derivatives as anticancer agents, there have been lim- ited studied on iso eugenol as an anticancer agent. Meanwhile isoeugenol has a highly cytotoxic effect by the induction of Reactive Oxygen Species (ROS) [11]. The cytotoxicity tested by using the MTT method showed that the $\mathrm{CC}_{50}$ of isoeugenol was $0.0523 \mathrm{mM}$, higher than eugenol was $0.395 \mathrm{mM}$ [12]. Isoeugenol as COX-2 inhibitor increases ROS by triggering oxidative stress which results in cell damage in cancer cells $[13,14]$. In the present study, we used Lipinski's rule to determine drug similarity [15] and using a virtual platforms screening based on protein structure [16]. The novelty of this study is to design a potential iso eugenol derivatives that is structurally modified as COX-2 inhibitor. The purpose of this study was to investigate the potential iso eugenol derivatives as inhibitors of COX-2 using a molecular docking approach. The energy-based docking method is based on knowledge of the approximate location of the ligand on the active site of the receptor, whereas the shape-based method are based on the assumption that the receptor and ligand molecular surface must match. The high affinity shows that the molecules bind<smiles>C/C=C/c1ccc(O)c(OC)c1</smiles>

(2)

(3)

(4)<smiles>COc1cc(C(C(C)C)N(c2ccccc2)c2ccc(O)cc2)ccc1O</smiles>

(9)
6)<smiles>COc1cc(C(C(C)O)N(C(=O)c2ccccc2O)c2ccccc2)ccc1O</smiles>

(10)<smiles>COc1cc(C(C(C)O)N(c2ccccc2)c2ccc(Br)cc2C)ccc1O</smiles>

(8)<smiles>COc1cc(C(C(C)O)N(C(=O)c2ccccc2)c2cccc(Cl)c2)ccc1O</smiles>

(11)

Figure 1. Aryl amino alcohol derivatives, molecule number 1 is isoeugenol, molecule number 2-4 are compounds coupling between aniline and $\mathrm{NO}_{2}$, molecule number 5-8 are compounds coupling between diphenylamine, $\mathrm{OH}$, and $\mathrm{NO}_{2}$, molecule number 9-11 are compounds coupling between aniline, carbox$\mathrm{yl}, \mathrm{OH}$, and $\mathrm{Cl}$. 
strongly each other. Some of potential compounds need further studied at later stages, such as in vitro and in vivo.

\section{Materials and Methods}

Three-dimensional structure molecules and all modelling were used software tools installed with a $1.9 \mathrm{GHz}$, RAM $8 \mathrm{~GB}$, Intel i5 processor running the Windows 10 operating system.

\subsection{Ligand Preparation}

Some of the aryl amino alcohol derivatives structures were generated by ChemDraw Ultra 8.0.3 and saved with mol. format files and the structures were optimized by AVOGADRO [17] and saved with PDB (Protein Data Bank) format files. All the ligand's toxicity properties were investigated with the help of admetSAR 2.0 [18]. The molecules of isoeugenol derivatives were designed by substituting the alkene with amine and hydroxyl group. The molecules structure are shown in Figure 1.

\subsection{Protein Preparation}

The crystal structure of the COX-2 enzyme was taken from Collaboratory for Structural Bioinformatics PDB https://www.rcsb.org/pdb Protein Data Bank (PDB) with code 5GMN
[19]. The preparation of the protein starts from removing the water and ligand molecules and other residual material using BIOVIA Discovery Studio 2020. The protein was saved with a PDB format file.

2.3 Molecular Docking of COX-2 and Aryl Amino Alcohol Derivatives

The binding affinity value was calculated from total desolvation energy, hydrogen bond energy, and Van Der Waals based on the total intermolecular energy ( $\mathrm{kcal} / \mathrm{mol})$. The PyRx screening was based on the energy transformation of the ligand-receptor structure which was given by the binding constant and Gibbs free energy $(\Delta G)$ values [20]. The Outputs of the dockings are saved as pdbqt files. Interaction between ligan and protein will show on the BIOVIA Discovery Studio 2020 program.

\section{Results and Discussions}

Ligan molecules were successfully prepared with using ChemDraw Ultra 8.0.3. as presented in Figure 1. As for comparison, commercial drugs are used Polmacoxib obtained from the Protein Data Bank (PDB) database. To assess the toxicity of aryl amino alcohol derivatives, we evaluate the drug discovery by using com-

Table 1. Toxicity and Physicochemical of aryl amino alcohol derivatives.

\begin{tabular}{|c|c|c|c|c|c|c|c|}
\hline No. & Compounds & MW & $\log \mathrm{P}$ & hERG inhibition & $\begin{array}{l}\text { Ames toxicity } \\
\text { (mutagenicity) }\end{array}$ & $\begin{array}{l}\text { Carcinogens } \\
\text { (binary) }\end{array}$ & $\begin{array}{c}\text { Acute Oral } \\
\text { Toxicity }\end{array}$ \\
\hline 1 & Isoeugenol (IE) & 164.2 & 2.43 & $\begin{array}{l}\text { non- inhibitor } \\
0.6425\end{array}$ & $\begin{array}{l}\text { Non AMES } \\
\text { Toxicity } 0.9500\end{array}$ & $\begin{array}{l}\text { non-carcinogens } \\
0.6429\end{array}$ & III 0.8899 \\
\hline 2 & IE-Anillin & 273.3 & 2.93 & $\begin{array}{l}\text { non- inhibitor } \\
0.4512\end{array}$ & $\begin{array}{l}\text { Non AMES } \\
\text { Toxicity } 0.7600\end{array}$ & $\begin{array}{l}\text { non-carcinogens } \\
0.8143\end{array}$ & III 0.8293 \\
\hline 3 & IE-An-OH(para)- $\mathrm{NO}_{2}$ & 334.33 & 2.23 & $\begin{array}{l}\text { non- inhibitor } \\
0.6008\end{array}$ & $\begin{array}{l}\text { Non AMES } \\
\text { Toxicity } 0.5700\end{array}$ & $\begin{array}{l}\text { non-carcinogens } \\
0.8000\end{array}$ & III 0.6242 \\
\hline 4 & IE-An-OH(para)- $\mathrm{NO}_{2}$ (meta) & 334.33 & 2.55 & $\begin{array}{l}\text { non- inhibitor } \\
0.5114\end{array}$ & $\begin{array}{l}\text { Non AMES } \\
\text { Toxicity } 0.5200\end{array}$ & $\begin{array}{l}\text { non-carcinogens } \\
0.8143\end{array}$ & III 0.6087 \\
\hline 5 & IE-Diphenylamine & 347.46 & 5.94 & $\begin{array}{l}\text { non- inhibitor } \\
0.5567\end{array}$ & $\begin{array}{l}\text { Non AMES } \\
\text { Toxicity } 0.6700\end{array}$ & $\begin{array}{l}\text { non-carcinogens } \\
0.7429\end{array}$ & III 0.7959 \\
\hline 6 & IE-Diphenyl-OH(para) & 365.42 & 4.37 & $\begin{array}{l}\text { non- inhibitor } \\
0.6689\end{array}$ & $\begin{array}{l}\text { Non AMES } \\
\text { Toxicity } 0.6333\end{array}$ & $\begin{array}{l}\text { non-carcinogens } \\
0.7968\end{array}$ & III 0.7401 \\
\hline 7 & IE-Diphenyl-OH(ortho-para) & 381.43 & 4.07 & $\begin{array}{l}\text { non- inhibitor } \\
0.6567\end{array}$ & $\begin{array}{l}\text { Non AMES } \\
\text { Toxicity } 0.6800\end{array}$ & $\begin{array}{l}\text { non-carcinogens } \\
0.8571\end{array}$ & III 0.7363 \\
\hline 8 & $\begin{array}{l}\text { IE-Diphenyl-OH(para)- } \\
\mathrm{NO}_{2} \text { (meta) }\end{array}$ & 410.43 & 4.27 & $\begin{array}{l}\text { non- inhibitor } \\
0.4786\end{array}$ & $\begin{array}{l}\text { Non AMES } \\
\text { Toxicity } 0.5100\end{array}$ & $\begin{array}{l}\text { non-carcinogens } \\
0.8429\end{array}$ & III 0.5980 \\
\hline 9 & IE-Benzanilide & 377.4 & 4.17 & $\begin{array}{l}\text { non- inhibitor } \\
0.4223\end{array}$ & $\begin{array}{l}\text { Non AMES } \\
\text { Toxicity } 0.54000\end{array}$ & $\begin{array}{l}\text { non-carcinogens } \\
0.8714\end{array}$ & III 0.7207 \\
\hline 10 & IE-Benzanilide-OH(ortho) & 393.44 & 3.88 & $\begin{array}{l}\text { non- inhibitor } \\
0.4597\end{array}$ & $\begin{array}{l}\text { Non AMES } \\
\text { Toxicity } 0.6300\end{array}$ & $\begin{array}{l}\text { non-carcinogens } \\
0.8857\end{array}$ & III 0.7710 \\
\hline 11 & IE-Benzanilide-Cl(meta) & 411.89 & 4.82 & $\begin{array}{l}\text { non- inhibitor } \\
0.4418\end{array}$ & $\begin{array}{l}\text { Non AMES } \\
\text { Toxicity } 0.6100\end{array}$ & $\begin{array}{l}\text { non-carcinogens } \\
0.8571\end{array}$ & III 0.7878 \\
\hline 12 & Polmacoxib & 361.39 & 2.72 & $\begin{array}{l}\text { non- inhibitor } \\
0.4420\end{array}$ & $\begin{array}{l}\text { Non AMES } \\
\text { Toxicity } 0.5200 \\
\end{array}$ & $\begin{array}{l}\text { non-carcinogens } \\
0.5645\end{array}$ & III 0.5626 \\
\hline
\end{tabular}

*MW $=$ Molecular Weight 
puter simulation admetSAR [21]. The drug similarity of any molecule can be estimated, but the actual specific effect (biological activity) achieved by the drug cannot be evaluated by using computer tools. Many of the best-selling drugs have a lower score on a variety of drug similarity indicators [20]. Table 1 describes the properties of the compound using the predicted $\log P$ values of admetSAR (logarithm of the compound's division coefficient between octanol and water), it's well established to measure hydrophilicity. The lower values of $\log P$ indicates higher hydrophilicity, high adsorption, and permeation. Lipinksi's rule predicts that poor absorption and permeation is more likely when Log $P$ is greater than 5 . The lower molecular weight enhances the adsorption rate and preferable as drug candidates. Small molecules weighing less than 500 have many advantages by biological processes, including easily penetrating the blood vessel barrier of the brain and intestines [22]. In this study, all derivatives of aryl amino alcohol have $\log P$ values ranging from 2.43 to 5.94 and the molecular weights are not more than 500. All the molecules follow the Lipinski's rule for $\log P$ except molecule no.5 IE-Diphenylamine.

The toxicity test for the candidate compounds used admetSAR with some parameters. The first parameter is Inhibition of hERG (the human Ether a go-go- related) which the gene that encodes the protein channel that potassium contributes to heart rate activity. The inhibition of this protein causes a fatal disruption to the heart [23]. The second parameter is mutagenicity that analyzed using the AMES method based on database 8445 compounds including 4912 toxic chemicals and 3533 nonmutagens toxic chemicals [24]. The third parameter is carcinogen potential using a computer-aided prediction of rodent carcinogenicity classified by Lagunin [25]. The oral toxicity acute shows that all compounds are in category III which means has an $L D$ value of $500-5000$ $\mathrm{mg} / \mathrm{kg}$. AdmetSAR toxicity computer simulations on Table 1 show that all compounds have little toxic effects with acute oral toxicity in category III and all compounds have noncarcinogenic effect.

Molecular docking was successfully carried out at the COX-2 receptor (ID: 5GMN) by using PyRx Vina. Docking is performed in the mooring area (grid) with center_x $=9.9569$, center $\mathrm{y}=1.52725$, center $\_\mathrm{z}=10.5322$. This step indicates the interaction of COX-2 enzyme. The binding energy is the main parameter produced by molecular docking. The values which show the highest negative means the compounds bind strongly with the protein. It gives us an illustration for the strength and affinity of the interaction between the ligand and the receptor. Binding energy is not the only parameter for new drug discovery, but it is possible to know if there are interactions through binding energy. Therefore, in this molecular docking study, we aim to find the ligand that exhibits the smallest binding energy and therefore has the best affinity between those molecules. The docking study result for molecule number 10 \& 11 have the lowest energy value $(\Delta \mathrm{G})=-8.3$ $\mathrm{kcal} / \mathrm{mol}$ and $-8.6 \mathrm{kcal} / \mathrm{mol}$. This result was the closest value compare with polmacoxib drug with $(\Delta \mathrm{G})=-8.9 \mathrm{kcal} / \mathrm{mol}$ as shown in Table 2 . The presence of halogen $\mathrm{Cl}$ and $\mathrm{OH}$ at molecular numbers 11 and 10 were suspected pushes the hydrophilic head towards the hydrophobic area, as shown in Figure 2. Molecular docking simulations were successfully performed on the COX-2 receptor (ID: 5GMN) by using Autodock vina and PyRx. The simulation is carried out by tethering the ligand (polmacoxib) to the known protein-binding active site with BIOVIA Discovery Studio 2020 program. Molecule number $10 \& 11$ have similar $\mathrm{H}$-bonding interaction on amino acid compare with polmacoxib drugs $\left(\mathrm{Arg}^{245}, \mathrm{Glu}^{14}, \mathrm{Pro}^{246}, \mathrm{Gln}^{248}, \mathrm{Ala}^{247}, \mathrm{Pro}^{30}\right.$, Pro $^{13}$, Trp ${ }^{244}$ ). This similarity defines the mechanism of action against the active protein competitively with polmacoxib on the COX-2 active site. Molecules 10 and 11 are promising candidates for the new anti-cancer as COX-2 inhibitor and should be considered in the next synthesis project, also need further test such as in vitro and in vivo.

\section{Conclusion}

This molecular docking study showed the presence of hydroxyl functional groups and halides in aromatic rings was able to increase the interaction at the COX-2 active site. Molecules no. 10 and 11 have low binding energies $(\Delta \mathrm{G})=$ $-8.3 \mathrm{kcal} / \mathrm{mol}$ and $-8.6 \mathrm{kcal} / \mathrm{mol}$, almost equals the binding energy value of the drug polmacoxib $(\Delta \mathrm{G})=-8.9 \mathrm{kcal} / \mathrm{mol}$. The binding energy is not the only parameter for new drug discovery, but it is possible to know if there are interactions through binding energy. In regard of the result on molecular docking study, we proposed a new class aryl amino alcohol derivatives from iso eugenol targeting as COX-2 in anti-breast cancer treatment. 


\section{Acknowledgement}

The authors thank to the Biomass Drug Food Development (BioDFD) Research Group and the Ministry of Higher Education Research and Technology Republic of Indonesia for providing research funding.

\section{References}

[1] Nagai, H., Kim, Y.H. (2017). Cancer prevention from the perspective of global cancer burden patterns. Journal of Thoracic Disease, 9, 448-451. DOI: $10.21037 /$ jtd.2017.02.75.

[2] Siegel, R.L., Miller, K.D., Jemal, A. (2020). Cancer statistics, 2020. CA: A Cancer Journal for Clinicians, 70, 7-30. DOI: 10.3322/caac. 21590 .

Table 2. The docking result of aryl amino alcohol derivatives - COX-2.

\begin{tabular}{|c|c|c|c|}
\hline No. & Molecules & $\begin{array}{l}\text { Binding } \\
\text { Affinity } \\
\text { (kcal/mol) }\end{array}$ & Interaction on amino acid \\
\hline 1 & Isoeugenol (IE) & -5.9 & $\mathrm{Arg}^{245}, \mathrm{Gln}^{248}, \mathrm{Pro}^{246}, \mathrm{Pro}^{30}$ \\
\hline 2 & IE-Anillin & -7.1 & $\mathrm{Arg}^{245}, \mathrm{Gln}^{248}, \mathrm{Pro}^{246}, \mathrm{Ala}^{247}, \mathrm{Val}^{31}, \mathrm{His}^{107}$ \\
\hline 3 & IE-An-OH(para)- $\mathrm{NO}_{2}$ & -6.4 & $\begin{array}{l}\mathrm{Arg}^{245}, \mathrm{Pro}^{246}, \mathrm{Ala}^{24}, \mathrm{Val}^{31}, \mathrm{Gln}^{28}, \mathrm{Ser}^{29}, \mathrm{Pro}^{30} \text {, } \\
\text { Glu106 }\end{array}$ \\
\hline 4 & IE-An-OH(para)- $\mathrm{NO}_{2}$ (meta) & -7.1 & 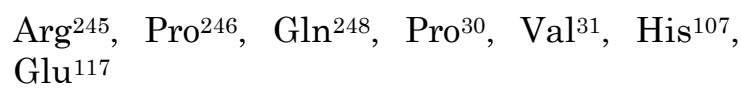 \\
\hline 5 & IE-Diphenylamine & -7.5 & $\begin{array}{l}\text { Arge25, Pro }{ }^{246}, \mathrm{Gln}^{248}, \mathrm{Pro}^{30}, \mathrm{Val}^{31}, \mathrm{His}^{107} \text {, } \\
\text { Glu }\end{array}$ \\
\hline 6 & IE-Diphenyl-OH(para) & -8.1 & $\operatorname{Arg}^{245}, \mathrm{Glu}^{14}, \mathrm{Pro}^{246}, \mathrm{Gln}^{248}, \operatorname{Trp}^{16}, \mathrm{Pro}^{30}$ \\
\hline 7 & IE-Diphenyl-OH(ortho-para) & -8.1 & $\operatorname{Arg}^{245}, \mathrm{Glu}^{14}, \mathrm{Pro}^{246}, \mathrm{Gln}^{248}, \operatorname{Trp}^{16}, \mathrm{Pro}^{30}$ \\
\hline 8 & IE-Diphenyl-OH(para)- $\mathrm{NO}_{2}$ (meta) & -7.9 & $\mathrm{Glu}^{14}, \mathrm{Gln}^{248}, \operatorname{Pro}^{246}, \operatorname{Pro}^{13}, \operatorname{Trp}^{16}$ \\
\hline 9 & IE-Benzanilide & -8.1 & $\begin{array}{l}\mathrm{Arg}^{245}, \operatorname{Pro}^{246}, \mathrm{Gln}{ }^{248}, \mathrm{Pro}^{30}, \mathrm{Gln}^{28}, \mathrm{Ala}^{247} \text {, } \\
\mathrm{Gln}^{28}, \mathrm{Ser}^{29}\end{array}$ \\
\hline 10 & IE-Benzanilide-OH(ortho) & -8.3 & $\begin{array}{l}\mathrm{Arg}^{245}, \mathrm{Pro}^{246}, \\
\mathrm{Ser}^{29}, \mathrm{Val}^{31}\end{array}$ \\
\hline 11 & IE-Benzanilide-Cl(meta) & -8.6 & $\begin{array}{l}\text { Arg }^{245}, \mathrm{Glu}^{14}, \mathrm{Pro}^{246}, \mathrm{Gln}^{248}, \mathrm{Ala}^{23}, \mathrm{His}^{15} \text {, } \\
\mathrm{Pro}^{13}\end{array}$ \\
\hline 12 & Polmacoxib & -8.9 & $\begin{array}{l}\text { Arg }^{245}, \mathrm{Glu}^{14}, \operatorname{Pro}^{246}, \mathrm{Gln}^{248}, \mathrm{Ala}^{247}, \mathrm{Pro}^{30}, \\
\text { Pro }^{13}, \operatorname{Trp}^{244}\end{array}$ \\
\hline
\end{tabular}
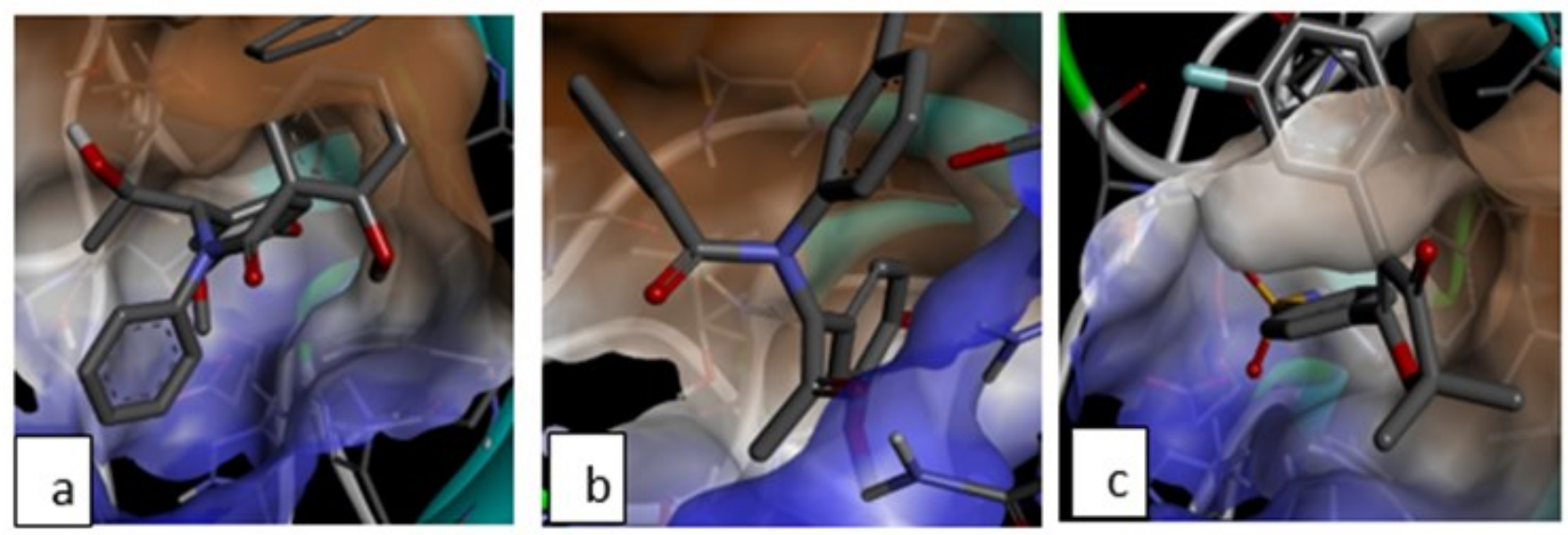

Figure 2. The interaction protein COX-2-ligan Isoeugenol with substituent $\mathrm{Cl}$ and carboxyl- molecule number 11 (a). Isoeugenol with substituent hydroxyl and carbonyl group-molecule number 10 (b). Polmacoxib drugs (c). 
[3] National Cancer Management Committee. (2013). Guidelines for Breast Cancer Management. Jakarta.

[4] DeNardo, D.G., Coussens, L.M. (2007). Inflammation and breast cancer. Balancing immune response: Crosstalk between adaptive and innate immune cells during breast cancer progression. Breast Cancer Research, 9, 212. DOI: $10.1186 /$ bcr 1746 .

[5] Allen, M.D., Jones, L.J. (2015). The role of inflammation in progression of breast cancer: Friend or foe? (Review). International Journal of Oncology, 47, 797-805. DOI: 10.3892/ijo.2015.3075.

[6] Mills, R.C. (2017). Breast Cancer Survivors, Common Markers of Inflammation, and Exercise: A Narrative Review. Breast Cancer: Basic and Clinical Research, 11, 1-12. DOI: 10.1177/1178223417743976.

[7] Harris, R.E., Casto, B.C., Harris, Z.M. (2014). Cyclooxygenase-2 and the inflammogenesis of breast cancer. World Journal of Clinical Oncology, 5, 677-692. D O I : 10.5306/wjco.v5.i4.677.

[8] Colin, B. (2013). Vascular and upper gastrointestinal eff ects of non-steroidal antiinflammatory drugs: meta-analyses of individual. The Lancet, 382, 769-779. DOI: 10.1016/S0140-6736(13)60900-9.

[9] Morris, G., Marguerita, L.-W. (2006). Molecular Docking. Encyclopedic Reference of Genomics and Proteomics in Molecular Medicine, 443, 1149-1153. DOI: 10.1007/3-54029623-9_3820.

[10] Fadilah, F., Yanuar, A., Arsianti, A., Andrajati, R., Purwaningsih, E.H. (2017). In silico study of aryl eugenol derivatives as anticolorectal cancer by inducing of apoptosis. Asian Journal of Pharmaceutical and Clinical Research, 10, 345-349. DOI: 10.22159/ajpcr.2017.v10i12.21233.

[11] Atsumi, T., Fujisawa, S., Satoh, K., Sakagami, H., Iwakura, I., Ueha, T., Sugita, Y., Yokoe, I. (2000). Cytotoxicity and radical intensity of eugenol, isoeugenol or related dimers. Anticancer Research, 20, 2519-2524. DOI: $10.1016 / \mathrm{s} 0300-483 \mathrm{x}(02) 00194-4$

[12] Atsumi, T., Fujisawa, S., Tonosaki, K. (2005). A comparative study of the antioxidant/prooxidant activities of eugenol and isoeugenol with various concentrations and oxidation conditions. Toxicology in Vitro, 19, 1025-1033. DOI: 10.1016/j.tiv.2005.04.012.

[13] Kim, S.J., Kim, H.S., Seo, Y.R. (2019). Understanding of ROS-Inducing Strategy in Anticancer Therapy. Oxidative Medicine and Cellular Longevity, 2019, 5381692. DOI: $10.1155 / 2019 / 5381692$.
[14] Bezerra, D.P., Militão, G.C.G., De Morais, M.C., De Sousa, D.P. (2017). The dual antioxidant/prooxidant effect of eugenol and its action in cancer development and treatment. Nutrients, 9(12), 1367 . DOI: 10.3390/nu9121367.

[15] Lipinski, C.A., Lombardo, F., Dominy, B.W., Feeney, P.J. (1997). Experimental and computational approaches to estimate solubility and permeability in drug discovery and development settings. Advanced Drug Delivery Reviews, 23, 3-25. DOI: 10.1016/S0169409X(96)00423-1.

[16] Vyas, V.K., Gupta, N., Ghate, M., Patel, S. (2014). Design, synthesis, pharmacological evaluation and in silico ADMET prediction of novel substituted benzimidazole derivatives as angiotensin II-AT1 receptor antagonists based on predictive 3D QSAR models. SAR and QSAR in Environmental Research, 25, $1 \quad 17-\begin{array}{lllllll} & 1 & & 4 & 6 & \text { D } & \text { O I : }\end{array}$ 10.1080/1062936X.2013.868825.

[17] Hanwell, M.D., Curtis, D.E., Lonie, D.C., Vandermeersch, T., Zurek, E., Hutchison, G.R. (2012). Avogadro: an advanced semantic chemical editor, visualization, and analysis platform. Journal of Cheminformatics, 262, 476-483. DOI: 10.1186/1758-2946-4-17 .

[18] Yang, H., Lou, C., Sun, L., Li, J., Cai, Y., Wang, Z., Li, W., Liu, G., Tang, Y. (2019). AdmetSAR 2.0: Web-service for prediction and optimization of chemical ADMET properties. Bioinformatics, 35, 1067-1069. DOI: 10.1093/bioinformatics/bty707.

[19] Kim, H.T., Cha, H., Hwang, K.Y. (2016). Structural insight into the inhibition of carbonic anhydrase by the COX-2-selective inhibitor polmacoxib (CG100649). Biochemical and Biophysical Research Communications, 478, 1-6. DOI: 10.1016/j.bbrc.2016.07.114.

[20] Trott, O., Olson, A.J. (2010). Autodock vina: improving the speed and accuracy of docking. Journal of Computational Chemistry, 31, 455-461. https://doi.org/10.1002/jcc.21334.

[21] Pratama, R., Ambarsari, L., Sumaryada, T.I. (2017). Molecular Interaction Analysis of COX-2 against Curcuminoid and Xanthorizol Ligand as Anti Breast Cancer using Molecular Docking. Current Biochemistry, 2, 139149. DOI: 10.29244/cb.2.3.139-149.

[22] Blake, J.F. (2000). Chemoinformatics - Predicting the physicochemical properties of "drug-like" molecules. Current Opinion in Biotechnology, 11, 104-107. DOI: 10.1016/S0958-1669(99)00062-2. 
[23] Zhou, P.Z., Babcock, J., Liu, L.Q., Li, M., Gao, Z.B. (2011). Activation of human ether-a-gogo related gene (hERG) potassium channels by small molecules. Acta Pharmacologica Sinica, $32, \quad 781-788$. DO I : 10.1038/aps.2011.70.

[24] Hansen, K., Mika, S., Schroeter, T., Sutter, A., ter Laak, A., Steger-Hartmann, T., Heinrich, N., Müller, K.-R. (2009). Benchmark data set for in silico prediction of Ames mutagenicity. Journal of Chemical Information and Modeling, 49, 2077-2081. DOI: 10.1021/ci900161g.
[25] Lagunin, A., Filimonov, D., Zakharov, A., Xie, W., Huang, Y., Zhu, F., Shen, T., Yao, J., Poroikov, V. (2009). Computer-aided prediction of rodent carcinogenicity by PASS and CISOC-PSCT. QSAR \& Combinatorial Science, 28, 806-810. D O I : 10.1002/qsar.200860192.

Selected and Revised Papers from $3^{\text {rd }}$ International Conference on Chemistry, Chemical Process and Engineering 2020 (IC3PE 2020) (https://chemistry.uii.ac.id/ic3pe/) (Universitas Islam Indonesia (UII), Labuan Bajo, Nusa Tenggara Timur, Indonesia by 30 $3{ }^{\text {th }}$ September - $1^{\text {st }}$ October 2020) after Peer-reviewed by Scientific Committee of IC3PE 2020 and Peer-Reviewers of Bulletin of Chemical Reaction Engineering \& Catalysis. Editors: Is Fatimah; I. Istadi. 